\title{
A Sleep Disorder Detection Model based on EEG Cross- Frequency Coupling and Random Forest
}

\author{
Stavros I. Dimitriadis ${ }^{1-6^{*}}$, Christos I. Salis ${ }^{2,7}$, Dimitris Liparas ${ }^{8}$ \\ 1 Cardiff University Brain Research Imaging Centre, School of Psychology, Cardiff \\ University, Cardiff, United Kingdom \\ 2 Neuroinformatics Group, Cardiff University Brain Research Imaging Centre, School \\ of Psychology, Cardiff University, Cardiff, United Kingdom \\ 3 Division of Psychological Medicine and Clinical Neurosciences, School of Medicine, \\ Cardiff University, Cardiff, United Kingdom \\ 4 School of Psychology, Cardiff University, Cardiff, United Kingdom \\ 5 Neuroscience and Mental Health Research Institute, School of Medicine, Cardiff \\ University, Cardiff, United Kingdom \\ 6 MRC Centre for Neuropsychiatric Genetics and Genomics, School of Medicine, \\ Cardiff University, Cardiff, United Kingdom \\ 7 Department of Electrical and Computer Engineering, University of Western \\ Macedonia, Kozani, Greece \\ 8 Research and Innovation Development, Intrasoft International S.A., Brussels, \\ Belgium
}

\section{*Corresponding author}

Dr. Stavros I.Dimitriadis

Cardiff University Brain Research Imaging Centre, School of Psychology, Cardiff University, Cardiff, United Kingdom

Head of Neuroinformatics Group

Email: Stavros I. Dimitriadis : stidimitriadis@gmail.com / DimitriadisS@cardiff.ac.uk

Email: Christos I.Salis: chsalis@uowm.gr, sal.christos@gmail.com

Email: Dimitris Liparas : dimitrios.liparas@gmail.com, dimitrios.liparas@intrasoft-intl.com 
medRxiv preprint doi: https://doi.org/10.1101/2020.06.10.20126268; this version posted January 15, 2021. The copyright holder for this preprint (which was not certified by peer review) is the author/funder, who has granted medRxiv a license to display the preprint in All rights reserved. No reuse allowed without permission.

\begin{abstract}
Study objectives: Sleep disorders are medical disorders of the sleep architecture of a subject, and based on their severity they can interfere with mental, emotional and physical functioning. The most common ones are insomnia, narcolepsy, sleep apnea, bruxism, etc. There is an increment risk of developing sleep disorders in elderly like insomnia, periodic leg movements, rapid eye movement (REM) behaviour disorders,sleep disorder breathing, etc. Consequently, their accurate diagnosis and classification are important steps towards an early stage treatment that could save the life of a patient. The Electroencephalographic (EEG) signal is the most sensitive and important biosignal, which is able to capture the brain sleep activity that is sensitive to sleep. In this study, we attempt to analyse EEG sleep activity via complementary cross-frequency coupling (CFC) estimates that will further feed a classifier, aiming to discriminate sleep disorders.
\end{abstract}

Methods: We adapted an open EEG Database with recordings that were grouped into seven sleep disorders and a healthy control. The EEG brain activity from common sensors has been analysed with two basic types of cross-frequency coupling (CFC). Finally, a Random Forest (RF) classification model was built on CFC patterns, that were extracted from non-cyclic alternating pattern (CAP) epochs.

Results: Our RF ${ }^{\mathrm{CFC}}$ model succeeded a 74\% multiclass accuracy. Both types of CFC, PAC and AAC patterns contribute to the accuracy of the RF model , thus supporting their complementary information.

Conclusion: CFC patterns, in conjunction with the RF classifier proved a valuable biomarker for the classification of sleep disorders.

Key words: sleep disorders, electroencephalography, cross-frequency coupling, random forest, classification

\title{
Statement of Significance
}

In this study, we developed an efficient model that is able to perform sleep disorder diagnosis by analysing the EEG sleep activity under the framework of cross-frequency coupling (CFC) with the support of RF. CFC has been proven an important mechanism that supports the integration of neural activity of different frequency content through a nested hierarchy of their oscillatory pattern inherent to distinct neural functions. Our results suggest that $\mathrm{CFC}$ can reflect aberrant physiological interactions during sleep stages, which are sensitive to differentiate 
medRxiv preprint doi: https://doi.org/10.1101/2020.06.10.20126268; this version posted January 15, 2021. The copyright holder for this preprint (which was not certified by peer review) is the author/funder, who has granted medRxiv a license to display the preprint in All rights reserved. No reuse allowed without permission.

sleep disorders. Therefore, our $\mathrm{RF}^{\mathrm{CFC}}$ model can be a valuable mental health tool for an accurate classification of those somnipathies.

\section{Introduction}

Electroencephalography (EEG) is the basic modality in sleep research, providing a noninvasive way to study brain dynamics in relationship to sleep [1]. Adult sleep is composed of non-rapid-eye-movement (NREM) and rapid-eye-movement (REM) brain states, which alternate almost every 90 minutes. Additionally, the NREM state is divided into four sleep stages, NREM1-4 [2]. Sleep is regulated by the circadian rhythm, which is an internal timer mechanism that maintains regular sleep timetable, hormone secretion and sustain oscillations in body temperature [3]. Normal sleep runs four or five cycles, including a passing from the four NREM stages and the state REM sleep.

Sleep disorders, no matter what the cause is, affect fifty to seventy million Americans spanning all the ages and socioeconomic classes [4]. This tremendous number of affected population can characterize them as a public healthy epidemic. They may be primarily due to an intrinsic problem that affects the sleep - wake cycle or secondary due to a medical condition [5]. Primary sleep disorders are divided into dyssomnias, which are further subdivided into intrinsic, extrinsic and circadian or parasomnias, which are subdivided into arousal disorders, sleep-wake transition disorders, parasomnias associated with REM Sleep and a fourth category of parasomnias [6].

The definition and distinction of those sleep stages are based upon the estimation of rhythmic neural oscillations during sleep that demonstrate different patterns [7] and provide a substrate to study how brain rhythms are related to cortical activity patterns and how this correlation varies across arousal levels [8]. Advanced signal processing techniques support a more detailed exploration of brain oscillations during sleep, which further advances our understanding of the related overcoming limitations of traditional quantification approaches, like how many minutes a person spent in each sleep stage, percentage of REM sleep compared to the total sleep time, or ratio-based sleep variables. Detection of sleep oscillations can be realized under visual inspection of oscillation events [9], automatic event detector algorithms like K-complexes [10], spectral analysis techniques [11, 12] and cross-frequency coupling (CFC) estimates [13]. 
medRxiv preprint doi: https://doi.org/10.1101/2020.06.10.20126268; this version posted January 15, 2021. The copyright holder for this preprint (which was not certified by peer review) is the author/funder, who has granted medRxiv a license to display the preprint in

All rights reserved. No reuse allowed without permission.

Interactions between activities with different frequency content and time scales have been widely explored in neuroscience to define a physiological biomarker, e.g. mild cognitive impairment [14], in mild traumatic brain injury [15], in sleep [13], etc. Neural activities with different frequency content have origin to cell population of different size and spatial orientation, while their interactions, named (CFC), are explored widely the last years $[8,16]$. CFC refers to interactions that can occur between brain rhythms with different frequency content, between different signals or within the same signals that capture brain activity of brain areas, correspondingly $[17,18]$. CFC has been adopted in studies that attempted to explore how information propagates across brain areas indicative of distinct neurophysiological functions [18-22]. In general, three basic types of CFC exist: phase synchronization (phase-phase CFC [23-24]), phase-amplitude coupling (PAC [14, 15, 21, 22]) and amplitude-amplitude coupling (AAC $[13,25])$.

In our recent study, we developed a single-sensor automatic sleep stage classification with high accuracy based on various types and estimators of CFCs [13]. We aim to develop the first model for an accurate sleep disorders detection based on EEG sleep activity with the incorporation of two types of CFC, the PAC and AAC. We hypothesized that the strength of CFC will be sensitive in different sleep stages across sleep disorders. As a proper classifier, we employ Random Forest (RF), which has proved efficient in many clinical problems [26]. Our first attempt focused on non-cyclic alternating pattern (CAP) patterns.

\section{Method}

\subsection{Material}

For the purpose of our study, we downloaded all night polysomnography (PSG) recordings from the well-known database: "The CAP Sleep Database" of "PhysioBank" (https://physionet.org/physiobank/database/capslpdb/) [27, 28]. This study is a collection of 108 PSG recordings that include seven groups with sleep disorders and a normal healthy one that did not present any medical, neurological or psychiatric disorder. The approval of the study has been registered in Sleep Disorders Center of the Ospedale Maggiore of Parma, Italy [27, 28]. Also, the clinical information for the whole cohort can be found in the excel file called "gender-age.xlsx". Well-trained sleep expert neurologists manually scored the sleep recordings based on the Rechtschaffen \& Kales rules classifying epochs as sleep stages 1-4, wake, REM sleep and movement artifacts [29]. Cycling Alternating Pattern (CAP) was determined based upon the Terzano's rules (phase-A subtypes include A1, A2 and A3) [27]. Furthermore, it 
medRxiv preprint doi: https://doi.org/10.1101/2020.06.10.20126268; this version posted January 15, 2021. The copyright holder for this preprint (which was not certified by peer review) is the author/funder, who has granted medRxiv a license to display the preprint in All rights reserved. No reuse allowed without permission.

should be noted that the EEG recordings were sampled were sampled at $100 \mathrm{~Hz}, 256$ or 512 Hz. We selected subjects with the same setup of EEG sensors and with frequency sampling of either 256 or $512 \mathrm{~Hz}$, considering that it is an important parameter in signal processing analysis. In our work, we excluded epochs annotated as movement artifacts.

\subsection{Signal Processing}

To reduce the effects of artefacts, we performed a combination of Fast Independent Component Analysis (ICA) and maximum overlap discrete wavelet transform (MODWT). Fast ICA was applied to the whole set of EEG sensors, giving an equal number of independent components with a characteristic topology and time course. Traditional artefact correction analysis based on ICA classifies an independent component as artefact or not. In the former case, researchers zeroed the whole component and the corresponding time course was considered as artefact. However, in most studies, an independent component doesn't reflect an artefact in the whole time course. As a result, setting it equal to zero leads to the elimination of the true brain activity. For that reason, every independent component time series was decomposed via wavelet transform and only subcomponents related to an artefact were deleted. Finally, the rest of wavelets subcomponents were reconstructed, giving rise to a clean independent component time series, which is then projected back to the original space. We adapted maximal overlap discrete wavelet transform to decompose every time source related to an independent component and especially Daubechies wavelets. We followed this waveletdriven decomposition every $5 \mathrm{sec}$ and employing a semi-supervised technique of estimating entropy, kurtosis and skewness, we assisted to zeroing or not wavelet subcomponents. Then, cleaned wavelet subcomponents were reconstructed to the original time series. The cleaned time courses of the independent component were back projected to the original recording EEG space.

Finally, we downsampled the PSG recordings with a frequency sampling rates of $512 \mathrm{~Hz}$ or $256 \mathrm{~Hz}$, in order to meet the lowest frequency sampling in the cohort, while subjects with 100 $\mathrm{Hz}$ were excluded from further analysis. We selected the following common EEG sensors provided by the cohort as a common template: P4-O2, F4-C4, C4-P4 and C4-A1. The number of participants that were used in our study with the related sleep disorder is provided in Table 1 . 
medRxiv preprint doi: https://doi.org/10.1101/2020.06.10.20126268; this version posted January 15, 2021. The copyright holder for this preprint (which was not certified by peer review) is the author/funder, who has granted medRxiv a license to display the preprint in All rights reserved. No reuse allowed without permission.

[Table 1 around here]

Scores are provided by experts with the following annotations:

Sleep stage (W=wake, S1-S4=sleep stages, R=REM, MT=body movements). In our study, we focused on S1-S4 and REM sleep stages.

PSD recordings were bandpass filtered in the following seven frequency bands : $\delta\{0.5-$ $4 \mathrm{~Hz}\}, \theta\{4-8 \mathrm{~Hz}\}, \alpha_{1}\{8-10 \mathrm{~Hz}\}, \alpha_{2}\{10-13 \mathrm{~Hz}\}, \beta_{1}\{14-20 \mathrm{~Hz}\}, \beta_{2}\{21-30 \mathrm{~Hz}\}$ and $\gamma_{1}\{31-$ $45 \mathrm{~Hz}\}$.

\subsection{CFC Estimations}

\subsubsection{Phase-to-amplitude coupling cross-frequency coupling (PAC)}

The most studied CFC in the literature is phase-to-amplitude coupling (PAC) [30]. In most studies, PAC was estimated between the phase of the slower rhythm and the amplitude of the faster oscillation. Here, we followed a different analytic approach, which was first presented in our previous works including an EEG sleep study [13, 14].

The PAC analytic approach for a single EEG P4-O2 sensor is described below:

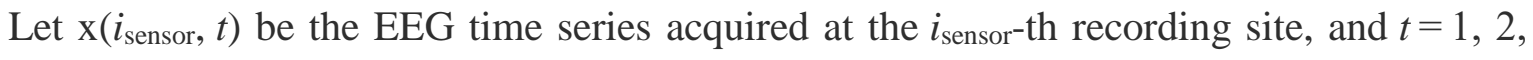
$\ldots T$ denotes the sample points. Given a bandpassed filtered signal of $\mathrm{x}\left(i_{\text {sensor }}, t\right)$, PAC is estimated between the phase of the lower-frequency (LF) oscillations and the amplitude of the higher-frequency (HF) ones. The following equations give a full representation of the complex transformations of both $(\mathrm{LF}) z_{\mathrm{LF}}(\mathrm{t})$ and $(\mathrm{HF})$ oscillations $z_{\mathrm{HF}}(\mathrm{t})$ extracted via the Hilbert transform (HT[.]).

$$
\begin{aligned}
& z_{L F}(t)=H T\left[x_{L F}(t)\right]=\left|z_{L F}(t)\right| e^{i \phi_{L F}(t)}=A_{L F}(t) e^{i \phi_{L F}(t)}, z_{H F}(t)=H T\left[x_{H F}(t)\right] \\
& =\left|z_{H F}(t)\right| e^{i \phi_{H F}(t)}=A_{H F}(t) e^{i \phi_{H F}(t)}
\end{aligned}
$$

This step gives rise to two time series that captured the envelope $A_{H F}(t)$ and the instantaneous phase $\phi_{\mathrm{LF}}(t)$ dynamics. The next step involved the bandpass filtering of the higher frequency oscillations $\mathrm{A}_{\mathrm{HF}}(t)$ within the range of LF oscillations and the resulting signal was Hilbert transformed to extract its phase-dynamics component $\varphi_{\mathrm{LF}-\mathrm{HF}}^{\prime}(\mathrm{t})$ : 
medRxiv preprint doi: https://doi.org/10.1101/2020.06.10.20126268; this version posted January 15, 2021. The copyright holder for this preprint (which was not certified by peer review) is the author/funder, who has granted medRxiv a license to display the preprint in All rights reserved. No reuse allowed without permission.

$$
\mathrm{z}^{\prime}(t)=\mathrm{HT}\left[A_{\mathrm{HF}, \mathrm{LF}}(t)\right]=\left|\mathrm{z}^{\prime}(\mathrm{t})\right| \mathrm{e}^{\mathrm{i} \phi_{\mathrm{HF}}^{\prime}(t)}=\left|\mathrm{z}^{\prime}(\mathrm{t})\right| \mathrm{e}^{\mathrm{i} \phi_{\mathrm{LF} \rightarrow \mathrm{HF}}(t)}
$$

The aforementioned equation reflects the HF-oscillations amplitude modulated by the phase of the LF-oscillations. The resulting time series will be employed to estimate PAC, by means of phase-locking (or synchronization index) technique.

PLV is defined as follows:

$$
P L V=\frac{1}{T} \sum_{t=1}^{T} e^{i\left[\phi_{L F}(t)-\phi_{H F}(t)\right]}
$$

iPLV is defined as follows:

$$
i P L V=\frac{1}{T}\left|\operatorname{Im}\left[\sum_{t=1}^{T} e^{i\left(\phi_{L F}(t)-\phi_{H F}(t)\right)}\right]\right|
$$

iPLV ranges between 0 and 1, with higher values indicating stronger comodulating PAC interactions.

Figure 1 illustrates every step of the CFC-PAC analysis, where a time series of $30 \mathrm{sec}$ length was adopted from the first subject with periodic leg movements during the NREM3 stage at the at $\mathrm{P} 4-\mathrm{O} 2$ sensor. PAC estimations are examined between the LF and HF oscillations, which were corresponded to $\delta$ and $\alpha_{1}$ brain rhythms, respectively. The original time series is presented in Figure 1A. The LF version of the original signal, along with the trace of its instantaneous phases $\phi_{\delta}(t)$ are depicted in Figure 1B. The corresponding HF version of the initial signal, along with the trace of its envelope $A_{\alpha 1}$ are depicted in Figure 1C. Figure 1D shows the low-pass filtered, within $\delta$ frequency range, version of the previous envelope [i.e., the $\mathrm{A}_{\alpha 1}, \delta(t)$ signal]. The saw-like trace corresponds to its instantaneous phases $\phi_{\alpha 1}^{\prime}(t)$. The $\phi_{\delta}(t)$ and $\phi_{\alpha 1}^{\prime}(t)$ traces have been plotted aligned in Figure 1E, forming the resulting instantaneous phase differences, as shown in Figure 1F. This resulting sequence, representing phase-differences $\Delta \phi(t)$, enters in equation (2) and will be integrated across time by averaging directional vectors $\mathrm{e}^{i \Delta \phi(t)}$ in the complex domain. The length of the original time series should be long enough so that the iPLV index results into a reliable estimation of PAC.

In the present study, we estimated PAC for a total of $(7 \times 6) / 2=21$ cross-frequency pairs per epoch. 
medRxiv preprint doi: https://doi.org/10.1101/2020.06.10.20126268; this version posted January 15, 2021. The copyright holder for this preprint (which was not certified by peer review) is the author/funder, who has granted medRxiv a license to display the preprint in All rights reserved. No reuse allowed without permission.

[Figure 1 around here]

\subsubsection{Amplitude-to-amplitude cross-frequency coupling (AAC)}

AAC is estimated between the Hilbert envelopes of bandpass filtered time series and by adopting correlation coefficient to quantify their coupling. In Fig.2, the algorithmic steps for the estimation of the AAC are illustrated. Fig. 2A depicts the same trace as the one used in Fig.1A, while Fig.2B and C illustrate the bandpass filtered traces and the related envelopes extracted via Hilbert transform for the low-frequency $\delta(0.5-4 \mathrm{~Hz})$ and the high-frequency $\alpha_{1}(13-20 \mathrm{~Hz})$, respectively. Figure 2D shows the common representation of those envelopes traces. The Pearson's correlation coefficient between every pair of the derived envelope time series was estimated to express the associations between specific frequency pairs. The AAC is computed as follows:

$A A C=\left|\frac{\sum_{i=1}^{n}\left(x_{i}-x\right)\left(y_{i}-y\right)}{\sqrt{\sum_{i=1}^{n}\left(x_{i}-x\right)^{2}} \sqrt{\sum_{i=1}^{n}\left(y_{i}-y\right)^{2}}}\right|$

where $\mathrm{n}$ is the sample size, $x_{i} y_{i}$ are the individual sample points indexed with $\mathrm{i}$ and

$x=\frac{1}{n} \sum_{i=1}^{n} x_{i}$ is the sample mean and analogously for $\mathrm{y}$.

Here, we took the absolute values of Pearson's correlation coefficient. In the present study, we estimated PAC for a total of $(7 \times 6) / 2=21$ cross-frequency pairs per epoch.

[Figure 2 around here]

\subsection{Feature Selection}

Our analytic plan extracts an important set of features tailored to CFC. We estimated (CFC) with both estimators across every pair of frequencies and separately for every epoch. Consequently, we averaged the CFC values across epochs of the same sleep stage independently for every subject. The total number of features is: 5 \{number of sleep stages $\mathrm{x}$ 2 \{number of connectivity estimators $\}$ x 21 \{possible pair of frequencies $\}=210$. This set of features was then fed into our Random Forest (RF) model. 
medRxiv preprint doi: https://doi.org/10.1101/2020.06.10.20126268; this version posted January 15, 2021. The copyright holder for this preprint (which was not certified by peer review) is the author/funder, who has granted medRxiv a license to display the preprint in All rights reserved. No reuse allowed without permission.

\subsection{Random Forest model and experimental setup}

\subsubsection{Random Forest}

The RF classifier is an ensemble learning method, used extensively in classification and regression tasks [31]. The methodology basically involves the construction of a group (called "forest") of decision trees as follows: each tree in the "forest" is built on a different training set (called bootstrap sample), drawn randomly from the original training data. A randomly selected variable subset (from the original variable set) is used (during the construction of each decision tree) in order to establish the best split at each node. Once the RF model has been trained and all trees in the forest are constructed, their decisions are combined through majority voting (classification) or averaging (regression). Then, those decisions are used in the prediction of unknown cases.

The RF algorithm provides an internal estimator of a constructed model's generalization error, called out-of-bag (OOB) error. The estimation of the OOB error involves each decision tree in the model as follows: a portion of the original data cases (around 1/3) do not participate in the training of each tree and instead they are utilized as "test" data, being predicted by the constructed tree. The OOB error estimate is the averaged prediction error for each training case, using only the trees that do not include that case in their bootstrap sample. For more details on the RF algorithm and its underlying notions, we refer for example to [26] and [32].

\subsubsection{Experimental setup}

In all RF models trained in our experiments, the following parameter setup was used: the number of trees for each model was empirically set based on the OOB error estimate. Following this approach, in all cases, the number of trees was set to 1000. For each RF model and for each node split during the growing of a tree, the number of variables used to determine the best split was set to the default $\sqrt{\mathrm{m}}(\mathrm{m}=$ total number of features in the dataset). In addition, the RF classifier has its own built-in feature selection method, which was used in order to select the most important features in every RF model. Consequently, only the selected features subsets were utilized for the training of the final RF models. Finally, a 10-fold cross-validation scheme was applied in all the experiments for the training of the classifier. It is worth mentioning, that our RF-related experiments was written in R, version 3.6.3 ${ }^{1}$. Then, the in-house software MATLAB 2019B was used for the estimation of the cross-frequency coupling estimates.

\footnotetext{
${ }^{1}$ https://www.r-project.org/
} 
medRxiv preprint doi: https://doi.org/10.1101/2020.06.10.20126268; this version posted January 15, 2021. The copyright holder for this preprint (which was not certified by peer review) is the author/funder, who has granted medRxiv a license to display the preprint in All rights reserved. No reuse allowed without permission.

\section{Results}

\subsection{Performance of Random Forest Model with CFC Features}

Our RF model achieved a high performance of $74 \%$ for the P4-O2 EEG sensor, with a macro-average precision of $83.7 \%$, a macro-average recall of $59.1 \%$ and a macro-average Fscore of $64.9 \%$ (Table 2). The rest of the EEG sensors performed worse compared to the optimal scenario: F4-C4 (56\%), C4-P4 (56\%) and C4-A1 (64\%) (see STables 1-3). Table 3 summarizes the confusion matrices of the RF model for the P4-O2 sensor. Finally, the confusion matrices for the other three sensors are presented in the supplementary material of the study (STables 4-6).

[Table 2,3 around here]

\subsection{The Complementarity of PAC-AAC CFC}

Figure 3 illustrates the seven features related to the AAC across the sleep stages. Figures 4 -8 demonstrate the twenty-eight selected features from the PAC independently per sleep stage. It is evident that PAC contributes the highest portion of selected features. However, both types encapsulate complementary information under the framework of CFC. The major frequency modulators across sleep stages were $\delta, \theta$ and $\alpha$. Interestingly, AAC features were across all the sleep stages with the exception of REM.

[Figures $3-8$ around here]

\subsection{The Importance of Sleep Stage 4}

We ran our RF model independently for every sleep stage with the main aim to rank the importance of sleep stages. Our findings ranked sleep stage 4 as the most informative compared to the other ones for the sleep disorder classification with an accuracy of $62 \%$.

\section{Discussion}

In the present study, we demonstrated the feasibility of a single-sensor sleep disorder classification model based on complementary CFC estimators and a valuable RF classifier. It is the very first work that attempted to classify seven sleep disorders and a healthy control 
medRxiv preprint doi: https://doi.org/10.1101/2020.06.10.20126268; this version posted January 15, 2021. The copyright holder for this preprint (which was not certified by peer review) is the author/funder, who has granted medRxiv a license to display the preprint in All rights reserved. No reuse allowed without permission.

group simultaneously via EEG sleep polysomnographic recordings. We achieved a high classification accuracy of $74 \%$ (with macro-average precision: $83.7 \%$, recall: $59.1 \%$, F-score: $64.9 \%$ ). It should be noted that the most informative common EEG sensor was P4-O2. Our analysis revealed that both types of CFC co-exist during sleep and share complementary information. We also observed similar trends in our recent study, in which we presented a single-sensor automatic sleep stage classification algorithm [13]. Additionally, analyses focusing on single-stage CFC patterns revealed that sleep stage 4 was the most informative in our RF model.

The entire methodology of the proposed multiclass sleep disorder detection model can be summarized as follows:

- We kept N3 and N4 as single sleep stages without attempting to merge them [33].

- We adopted an ICA and MODWT (independent component analysis and maximum overlap discrete wavelet transform) to denoise the EEG recordings from eye movements and muscle activity.

- We estimated two different connectivity estimators per frequency pair and for every epoch (one phase-to-amplitude: PAC and one amplitude-to-amplitude: AAC).

- We used a dataset that includes subjects covering seven sleep disorders and a healthy group.

Previous studies have attempted to either characterize PAC CFC patterns in sleep disorders or to discriminate sleep disorders using the same dataset. A recent work reported for the very first time that PAC patterns of $\delta$ phase modulate $\alpha$ and low- $\beta$ amplitude in sleep disorders for the three CAP phases [34]. They adopted modulation index as a proper PAC estimator reporting the group-averaged PAC values for the two cross-frequency pairs. This study showed how PAC patterns differed across the three CAP phases at every sleep disorder and also how they differed at every CAP phase across sleep disorders. However, the authors focused only on PAC CFC estimates and only on two cross-frequency pairs without reporting any classification performance. They extracted frequency dependent signature using an adaptive filtering called empirical mode decomposition (EMD). Another work analysed the same dataset using discrete wavelet transform and related features were extracted [35]. Nonetheless, the authors reported their findings probably by averaging across both epochs and sleep stages with no statistical comparisons between sleep disorders. Moreover, there is no information about the common EEG sensors, from which they estimated and averaged the wavelet-based features. No classification performance has been reported. The third study decomposed every time source into frequency-dependent time courses using EMD, as in the first study [36]. The analysis 
medRxiv preprint doi: https://doi.org/10.1101/2020.06.10.20126268; this version posted January $15,2021$. The copyright holder for this preprint (which was not certified by peer review) is the author/funder, who has granted medRxiv a license to display the preprint in All rights reserved. No reuse allowed without permission.

focused on 20 healthy subjects, 20 REMs, 20 PLMs, and 20 patients with Apnea from the same dataset. For every EEG time source, EMD returns a data-driven set of intrinsic mode functions called IMFs. Every IMF has a characteristic temporal pattern with a specific frequency profile that can be assigned to well-known brain frequencies. The authors reported that their analysis revealed 9 IMFs, from which high-order statistics has been estimated, like Shannon Entropy, Spectral Entropy, Skewness and Kurtosis and the first order statistic Standard deviation. Then, they followed a classification approach reporting high performance (93\%) between the three sleep disorders and the healthy control group for features related to IMF8. However, they didn't report how and where the whole methodology was applied, which sensor they analysed, as well as how they managed the different epochs and the sleep stages. None of the aforementioned studies denoised the original EEG traces.

Brain frequencies can couple between each other via different but complementary mechanisms. The basic CFC mechanisms are phase-to-amplitude (PAC) and amplitude-toamplitude envelope correlation (AAC) [37, 38]. The first CFC mechanism, called PAC, quantifies how the phase of the slow frequency modulates the amplitude of the higher frequency. The explanation of the existence of such a mechanism and how slow oscillations can couple faster brain frequencies in many brain areas is on the conduction velocities of cortical neurons. Slower frequencies activate more neurons in large brain volumes associated with large changes of membrane potential [39]. This practically means that in longer temporal windows a larger portion of spikes linked to upstream neurons can co-exist [40]. There are evidences that PAC exists between every possible pair of mammalian brain frequencies from $0.025 \mathrm{~Hz}$ up to $500 \mathrm{~Hz}[41]$ and in sleep [13, 42]. A complementary CFC mechanism to PAC is the AAC, which captures the temporal covariation between the envelopes of the slower and the faster frequencies [43]. This approach is temporally less precise, but important to capture CFC mechanisms in many cases and especially in sleep [13].

In our study, we identified that the P4-O2 EEG sensor provided the highest accuracy among the four common EEG sensors. NREM 4 was also the most informative sleep stage following a classification process independently for every sleep stage. Our analysis supported the notion of analysing NREM 3 and 4 separately. The conclusion is that the combination of PAC and AAC in NREM 4 estimated over parieto-occipital brain area provided the most powerful sleep disorder detection model so far in the literature. It is known that consolidation processes rely on the interactions between characteristic brain oscillatory activity of NREM sleep: slow oscillations, spindles and ripples [44]. A recent study measured intracranial EEG activity 
medRxiv preprint doi: https://doi.org/10.1101/2020.06.10.20126268; this version posted January 15, 2021. The copyright holder for this preprint (which was not certified by peer review) is the author/funder, who has granted medRxiv a license to display the preprint in All rights reserved. No reuse allowed without permission.

during sleep from epileptic patients. They reported PAC between $0.5-1.25 \mathrm{~Hz}$ (slow oscillation range) and $12-16 \mathrm{~Hz}$ (spindle range) within the $\mathrm{Cz}$ sensor. Their findings were also evaluated from intracranial recordings from hippocampus, providing a link of PAC estimates between EEG sensor activity and intracranial findings. PAC estimates revealed the hierarchical role of slow oscillations, spindles and ripples during NREM [44]. A sleep study using intracranial EEG recordings from epileptic patients attempted to categorize sleep spindles based on their origin, frequency and their association with slow waves. Sleep spindles occur across multiple neocortical regions, including less frequent to hippocampus and parahippocampal brain areas [45]. They found that events in hippocampus co-occur more often with spindles that can be captured by EEG sensors located over frontal/parietal areas.

Human hippocampus generates sharp-wave ripples (SWRs) [46]. Posterior human hippocampus generates SWRs and a similar amount of spindle ripples (SSRs). Both SWRs and SSRs often co-occur with theta bursts, down states, sleep spindles and up states, which all coordinate interactions between cortex and hippocampus facilitating memory consolidation. SWRs co-generate with these types of waves across the cortex and especially in fronto-central areas. However, SSRs occur around $350 \mathrm{~ms}$. later, demonstrating a strong preference for cogeneration with parietal sleep spindles. Sleep spindles generated from the posterior part of hippocampus were shown to be strongly phase-locked with sleep spindles from parietal brain areas, while sleep ripples generated from the posterior part of hippocampus were strongly phase-coupled with sleep spindles generated from both parietal areas and the posterior part of hippocampus [47]. Our findings and selected CFC features in NREM stages could be related to the aforementioned hippocampal sharpwave ripples co-occuring with the variety of cortical sleep waves. Different parts of hippocampus produced sharpwave ripples independently to each other that interact with preferred cortical brain areas. The spatiotemporal orchestration of sharpwave ripples with cortical waves supported the cortico-hippocampo-cortical interaction which is affected in sleep disorders [48].

To the best of the authors' knowledge, the current study provided the best performance of a sleep disorder detection model in the literature. Our analysis involved the estimation of two CFC mechanisms among many frequency pairs within four common EEG sensors and across five sleep stages. The RF model served as a natural multiclass classifier and not as a oneversus-all classification approach. This work is another support of CFC existence during sleep [13]. In the future, we will adopt the same strategy tailored to the three CAP phases in 
medRxiv preprint doi: https://doi.org/10.1101/2020.06.10.20126268; this version posted January $15,2021$. The copyright holder for this preprint (which was not certified by peer review) is the author/funder, who has granted medRxiv a license to display the preprint in All rights reserved. No reuse allowed without permission.

conjunction with complementary CAP rates, like the ratio of the durations in secs between NREM CAP sleep and total NREM sleep [49].

This study provides evidence that two basic CFC are sensitive to detect alterations of nested oscillations across sleep disorders in various sleep stages. Additionally, PAC and AAC showed that they capture complementary information in relation to CFC mechanisms. Here, our study focused on the estimation of CFC within sensors and only in non-CAP epochs. Further analysis is important to explore CFC patterns between EEG sensors and also in CAP epochs. We aim to explore the aforementioned scenarios in a complementary study with the same dataset. Additionally, the classification performance of CFC patterns should be compared also with various definitions of CAP rates to further validate their importance in an accurate sleep disorder detection model. Moreover, a relationship between CFC patterns and CAP rates should be reported. One of the limitations of this study comes from the restrictions of the current database. More subjects are needed to further cross-validate our model, while a highdensity EEG sleep recording of subjects with sleep disorders would support the source localization of brain activity in virtual brain areas to explain current findings with CFC. 
medRxiv preprint doi: https://doi.org/10.1101/2020.06.10.20126268; this version posted January 15, 2021. The copyright holder for this preprint (which was not certified by peer review) is the author/funder, who has granted medRxiv a license to display the preprint in All rights reserved. No reuse allowed without permission.

\section{Author Contributions}

Stavros I. Dimitriadis: conceptualization, methodology, formal analysis, software, writing (original draft).

Christos I. Salis: data curation, performed the analysis, writing (reviewing and editing).

Dimitris Liparas: data curation, performed the machine learning, writing (reviewing and editing).

Every author read and approved the final version of the manuscript.

\section{Funding}

SID was supported by MRC grant MR/K004360/1 (Behavioral and Neurophysiological Effects of Schizophrenia Risk Genes: A Multi-locus, Pathway Based Approach) and by a MARIECURIE COFUND EU-UK Research Fellowship.

\section{Conflict of Interest}

The authors declare that the research was conducted in the absence of any commercial or financial relationships that could be construed as a potential conflict of interest.

\section{Acknowledgments}

We would like to acknowledge researchers, staff and technicians that made this dataset available to the public. Special thanks also to staff and scientists that maintain physionet database active.

\section{Disclosure Statement}

- Financial Disclosure: none.

- Non-financial Disclosure: none 
medRxiv preprint doi: https://doi.org/10.1101/2020.06.10.20126268; this version posted January 15, 2021. The copyright holder for this preprint (which was not certified by peer review) is the author/funder, who has granted medRxiv a license to display the preprint in All rights reserved. No reuse allowed without permission.

\section{References}

1. Younes $M$. The case for using digital EEG analysis in clinical sleep medicine. SSP. 2017; 1(1): 2

2. Solms, M. Dreaming and REM sleep are controlled by different brain mechanisms. Behav. Brain Sci. 2000; 23(6): 843-850.

3. Zee P. C., Vitiello MV. Circadian rhythm sleep disorder: irregular sleep wake rhythm type. Sleep Med. Clin. 2009; 4(2): 213-218.

4. Thorpy M. J. Classification of sleep disorders. Neurotherapeutics. (2012); 9(4): 687701.

5. National Institutes of Health. National Institutes of Health Sleep Disorders Research $\begin{array}{llll}\text { Plan.Last } & \text { accessed } & \text { May } & 30,\end{array}$ https://www.nhlbi.nih.gov/files/docs/ncsdr/201101011NationalSleepDisordersResearc hPlanDHHSPublication11-7820.pdf.

6. Sleep Disorder Classifications - SleepHealth, SleepHealth, 2020. Accessed: 31- May2020 https://www.sleephealth.org/sleep-health/sleep-disorder-classifications/.

7. Davis H., Davis P. A., Loomis A. L., Harvey E. N., Hobart G. Human brain potentials during the onset of sleep. J. Neurophysiol. 1938; 1(1): 24-38.

8. Canolty R. T., Knight R. T. The functional role of cross-frequency coupling. Trends Cogn. Sci. 2010; 14 (11): 506-515. doi: 10.1016/j.tics.2010.09.001.

9. Haustein W., Pilcher J., Klink J., Schulz H. Automatic analysis overcomes limitations of sleep stage scoring. Electroencephalogr. Clin. Neurophysiol. 1986; 64(4): 364-374. doi: 10.1016/0013-4694(86)90161-6.

10. Al-Salman W., Li Y., Wen P. Detection of EEG k-complexes using fractal dimension of time frequency images technique coupled with undirected graph features. Front. Neuroinform. 2019; 13: 45. https://doi.org/10.3389/fninf.2019.00045

11. Jenni O. G., Carskadon M. A. Spectral analysis of the sleep electroencephalogram during adolescence. Sleep. 2004; 27 (4): 774-783.

12. Kurth S., Ringli M., Geiger A., LeBourgeois M., Jenni O. G., Huber R. Mapping of cortical activity in the first two decades of life: a high-density sleep electroencephalogram study. J Neurosci. 2010; 30 (40): 13211-13219.

13. Dimitriadis S. I., Salis C., Linden D. A novel, fast and efficient single-sensor automatic sleep-stage classification based on complementary cross-frequency coupling estimates. Clinical Neurophysiology. 2018; 129 (4): 815-828 
medRxiv preprint doi: https://doi.org/10.1101/2020.06.10.20126268; this version posted January 15, 2021. The copyright holder for this preprint (which was not certified by peer review) is the author/funder, who has granted medRxiv a license to display the preprint in All rights reserved. No reuse allowed without permission.

14. Dimitriadis S. I., Laskaris N. A., Bitzidou M. P., Tarnanas I., Tsolaki M.. A novel biomarker of amnestic MCI based on dynamic Cross-Frequency Coupling patterns during cognitive brain responses. Front. Neurosci. 2015; 9: 350. doi: 10.3389/fnins.2015.00350

15. Antonakakis, M., Dimitriadis, S. I., Zervakis, M., Rezaie, R., Babajani-Feremi, A., Micheloyannis, S., et al. Detecting mild traumatic brain injury from resting-state MEG recordings based on Cross-frequency Interactions. Int. J. Psychophysiol. 2016; 102: 111.

16. Belluscio M. A., Mizuseki K., Schmidt R., Kempter R., Buzsáki G. Cross-frequency phase-phase coupling between theta and gamma oscillations in the hippocampus. J. Neurosci. 2012; 32 (2): 423-435.

17. Jensen O., Colgin L. L. Cross-frequency coupling between neuronal oscillations. Trends Cogn. Sci. 2007; 11(7): 267-269.

18. Axmacher, N. et al. Cross-frequency coupling supports multi-item working memory in the human hippocampus. (2010) Proc. Natl. Acad.Sci. 107, 3228-3233.

19. A. Schnitzler and J. Gross, Normal and pathological oscillatory communication in the brain. 2005; Nat. Rev. Neurosci., 6 (4): 285-296.

20. Canolty R. T., Edwards E., Dalal S. S., Soltani M., Nagarajan S. S., Kirsch H. E., Berger M. S., Barbaro N. M., Knight R. T. High gamma power is phase-locked to theta oscillations in human neocortex, Science, 2006; 313 (5793): 1626-1628.

21. Scheffzük C., Kukushka V. I., Vyssotski A. L., Draguhn A., Tort A. B. L., Brankačk J., Selective coupling between theta phase and neocortical fast gamma oscillations during REM-sleep in mice, PloS One, 2011; 6 (12): e28489.

22. Szczepanski S. M., Crone N. E., Kuperman R. A., Auguste K. I., Parvizi J., Knight R. T., Dynamic changes in phase-amplitude coupling facilitate spatial attention control in fronto-parietal cortex. PLoS Biol., 2014; 12(8): e1001936.

23. Palva J. M., Palva S., Kaila K. Phase synchrony among neuronal oscillations in the human cortex. J. Neurosci. 2005; 25 (15): 3962-3972.

24. Dimitriadis S. I., Sun Y. U., Kwok K., Laskaris N. A., Thakor N., Bezerianos A. Cognitive workload assessment based on the tensorial treatment of EEG estimates of cross-frequency phase interactions. Ann. Biomed. Eng. 2015; 43 (4): 977-989. doi: 10.1007/s10439-014-1143-0 
medRxiv preprint doi: https://doi.org/10.1101/2020.06.10.20126268; this version posted January 15, 2021. The copyright holder for this preprint (which was not certified by peer review) is the author/funder, who has granted medRxiv a license to display the preprint in All rights reserved. No reuse allowed without permission.

25. Shirvalkar P. R., Rapp P. R., Shapiro M. L. Bidirectional changes to hippocampal thetagamma comodulation predict memory for recent spatial episodes, Proc. Natl. Acad. Sci., 2010; 107 (15): 7054-7059

26. Dimitriadis SI, Liparas D, Tsolaki MN. Alzheimer's Disease Neuroimaging Initiative. Random forest feature selection, fusion and ensemble strategy: Combining multiple morphological MRI measures to discriminate among healhy elderly, MCI, cMCI and alzheimer's disease patients: From the alzheimer's disease neuroimaging initiative (ADNI) database. J Neurosci Methods. 2018; 302: 14-23.

27. Terzano, M. G. et al. Atlas, rules, and recording techniques for the scoring of cyclic alternating pattern (CAP) in human sleep. Sleep Med. 2001; 2 (6): 537-553.

28. Goldberger A. L. et al. PhysioBank, PhysioToolkit, and PhysioNet: Components of a new research resource for complex physiologic signals. Circulation, 2000; 101 (23): e215-e220.

29. Wolpert E. A. A manual of standardized terminology, techniques and scoring system for sleep stages of human subjects. Arch. Gen. Psychiatry. 1969; 20 (2): 246-247.

30. Voytek B., Canolty R.T., Shestyuk A., Crone N.E., Parvizi J., Knight R.T. Shifts in gamma phase-amplitude coupling frequency from theta to alpha over posterior cortex during visual tasks. Front. Hum. Neurosci. 2010; 4: 19

31. Breiman, L. Random forests. Machine learning, 2001; 45 (1): 5-32.

32. Liparas D., HaCohen-Kerner Y., Moumtzidou A., Vrochidis S., Kompatsiaris I. News articles classification using random forests and weighted multimodal features. In Information Retrieval Facility Conference, 2014; 63-75. Springer, Cham.

33. Tsinalis O, Matthews PM, Guo Y. Automatic sleep stage scoring using time frequency analysis and stacked sparse autoencoders. Ann. Biomed. Eng. 2016; 44(5): 1587-1597.

34. Yeh C. H., Shi W. Identifying phase-amplitude coupling in cyclic alternating pattern using masking signals, Sci. Rep., 2018; 8(1): 2649.

35. Rao T., Vishwanath D. D. Detecting sleep disorders based on EEG signals by using discrete wavelet transform. In: 2014 International conference on green computing communication and electrical engineering (ICGCCEE). 2014: 1-4, Coimbatore, India.

36. Islam M.R., Rahim M.A., Akter H., Kabir R., Shin J.: Optimal IMF selection of EMD for sleep disorder diagnosis using EEG signals. In: Proceeding of the 3rd International Conference on Applications in Information Technology, 2018: 96-101, AizuWakamatsu, Japan. 
medRxiv preprint doi: https://doi.org/10.1101/2020.06.10.20126268; this version posted January 15, 2021. The copyright holder for this preprint (which was not certified by peer review) is the author/funder, who has granted medRxiv a license to display the preprint in All rights reserved. No perpetuity.

37. Buzsaki G, Draguhn A. Neuronal oscillations in cortical networks. Science, 2004; 304: 1926-1929. https://doi.org/10.1126/science.1099745.

38. Buzsáki G, Watson BO. Brain rhythms and neural syntax: implications for efficient coding of cognitive content and neuropsychiatric disease. Dialogues Clin Neurosci 2012; 14 (4): 345-367.

39. Von Stein A, Sarnthein J. Different frequencies for different scales of cortical integration: from local gamma to long range alpha/theta synchronization. Int $\mathbf{J}$ Psychophysiol 2000; 38 (3): 301-313. https://doi.org/10.1016/S0167- 8760(00) 001720 .

40. Quilichini P, Sirota A, Buzsaki G. Intrinsic circuit organization and theta-gamma oscillation dynamics in the entorhinal cortex of the rat. J Neurosci, 2010; 30 (33): 11128-11142.

41. Sirota A, Csicsvari J, Buhl D, Buzsaki G. Communication between neocortex and hippocampus during sleep in rodents. Proc Natl Acad Sci USA. 100 (4) 2003; 100 (4): 2065-2069.

42. Amiri M, Frauscher B, Gotman J. Phase-amplitude coupling is elevated in deep sleep and in the onset zone of focal epileptic seizures. Front Hum Neurosci 2016; 10: 387 https://doi.org/10.3389/fnhum.2016.00387.

43. Bruns A., Eckhorn R., Gail A., Brinksmeyer H. J., Schanze T. Directional coupling of gamma-envelopes and theta-signals between separate neuronal populations in human and monkey visual cortex. Soc. Neurosci. Abstr., 2001; 27: 36.

44. Staresina B. P., Bergmann T. O., Bonnefond M., Van der Meij R., Ole J., Deuker L., et al. Hierarchical nesting of slow oscillations, spindles and ripples in the human hippocampus during sleep. Nat Neurosci, 2015; 18: 1679-1686.

45. Andrillon T., Nir Y., Staba R. J., Ferrarelli F., Cirelli C., Tononi G., Fried I. Sleep spindles in humans: Insights from intracranial EEG and unit recordings. J. Neurosci. 2011; 31 (49): 17821-17834.

46. Buzsáki G. Hippocampal sharp wave-ripple: A cognitive biomarker for episodic memory and planning. Hippocampus, 2015; 25 (10): 1073-1188.

47. Jiang X, Gonzalez-Martinez J and Halgren E. Posterior hippocampal spindle-ripples cooccur with neocortical theta-bursts and down-upstates, and phase-lock with parietal spindles during NREM sleep in humans. Journal of Neuroscience, 2019; 39 (45): 8949-8968; 
medRxiv preprint doi: https://doi.org/10.1101/2020.06.10.20126268; this version posted January $15,2021$. The copyright holder for this preprint (which was not certified by peer review) is the author/funder, who has granted medRxiv a license to display the preprint in All rights reserved. No reuse allowed without permission.

48. Jiang X, Gonzalez-Martinez J and Halgren E. Coordination of human hippocampal sharpwave ripples during NREM sleep with cortical theta bursts, spindles, downstates, and upstates.J. Neurosci., 39 (2019), pp. 8744-8761

49. Terzano M. G., Mancia D., Salati M. R., Costani G., Decembrino A., Parrino L. The cyclic alternating pattern as a physiologic component of normal NREM sleep. Sleep, 1985; 8 (2): 137-145. 
medRxiv preprint doi: https://doi.org/10.1101/2020.06.10.20126268; this version posted January 15, 2021. The copyright holder for this preprint (which was not certified by peer review) is the author/funder, who has granted medRxiv a license to display the preprint in All rights reserved. No reuse allowed without permission.

\section{Figure Captions}

A

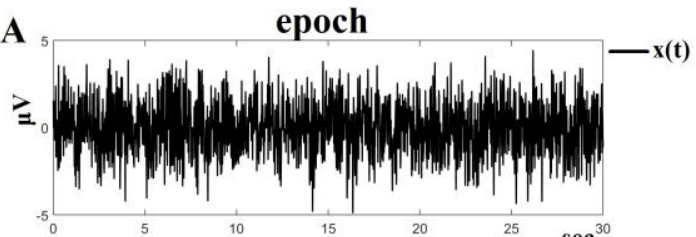

C
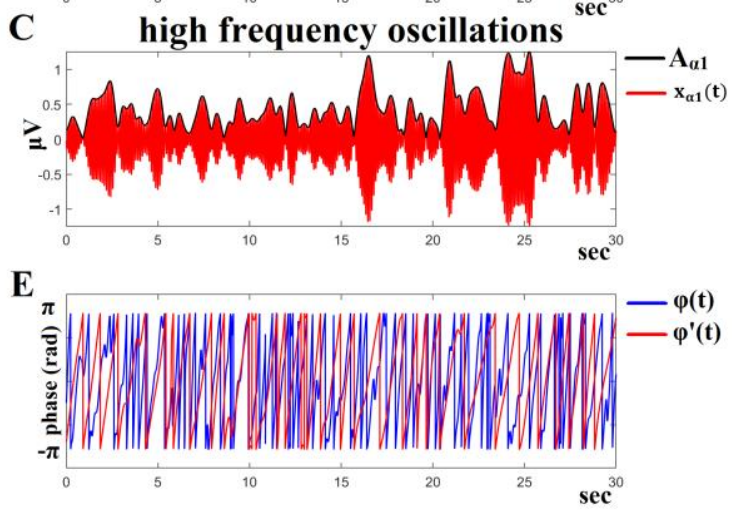

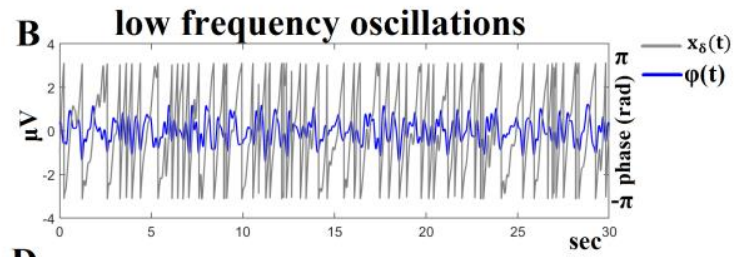

D
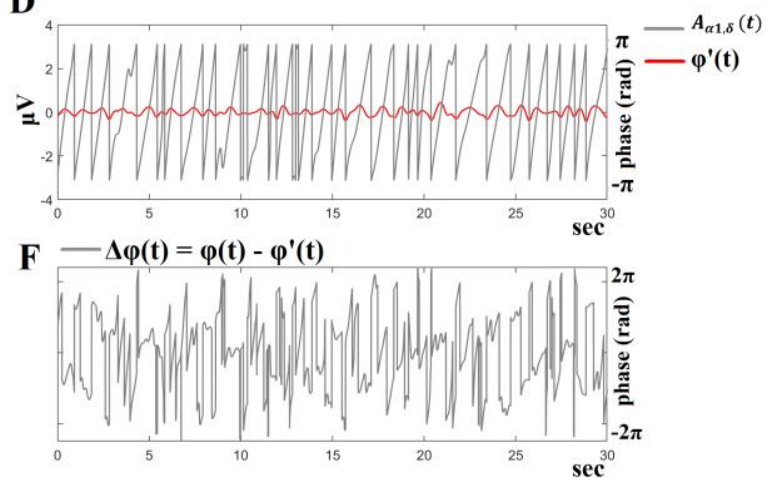

Figure 1. Algorithmic steps for PAC estimation.

Using an epoch of $30 \mathrm{sec}$ length recorded at the P4-O2 sensor from the first subject with periodic leg movements during the NREM3 stage (A), we showed the phase-to-amplitude coupling between $\delta$ and $\alpha_{1}$ rhythms. The time series presented in (A) was firstly bandpass filtered using a zero-phase-order filter into a low-frequency $\delta(0.5-4 \mathrm{~Hz})$ component, where its envelope via Hilbert transform was also extracted (B), and secondly into a high-frequency $\alpha_{1}(8-13 \mathrm{~Hz})$ component, where its envelope was extracted via Hilbert transform $(\mathrm{C})$. We then filtered the amplitude of the envelope high-frequency $\alpha_{1}$ (D) within the $\delta$ frequency range $(0.5-$ $4 \mathrm{~Hz}$ ). This algorithmic step is important because it will provide us with the $\delta$ modulation within the lower $\alpha_{1}$ amplitude. (E) Subsequently, we performed the Hilbert transformation at both the $\delta$-filtered signal and the $\theta$-filtered within the lower- $\alpha$ amplitude, extracting the related phase dynamics and, finally, their phase consistency with iPLV. The phase differences of those two-phase time series are illustrated in $(F)$ and will then enter into the iPLV estimator to quantify the strength of PAC coupling between $\delta$ and $\alpha_{1}$ rhythms. Consequently, the aforementioned CFC-PAC analysis will determine how the phase of the lower-frequency component modulates the amplitude of the high-amplitude component. 
medRxiv preprint doi: https://doi.org/10.1101/2020.06.10.20126268; this version posted January 15, 2021. The copyright holder for this preprint (which was not certified by peer review) is the author/funder, who has granted medRxiv a license to display the preprint in All rights reserved. No reuse allowed without permission.

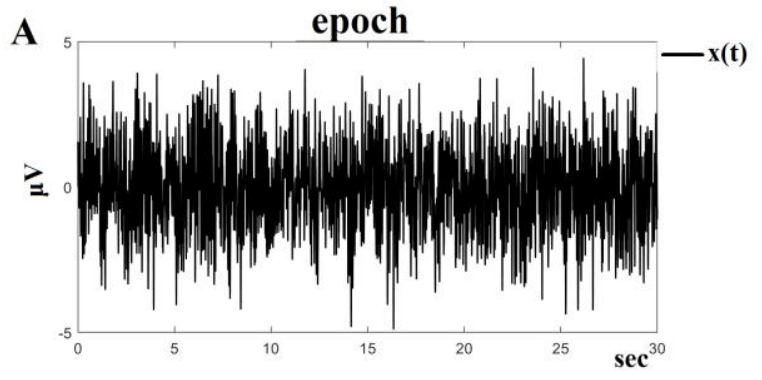

C

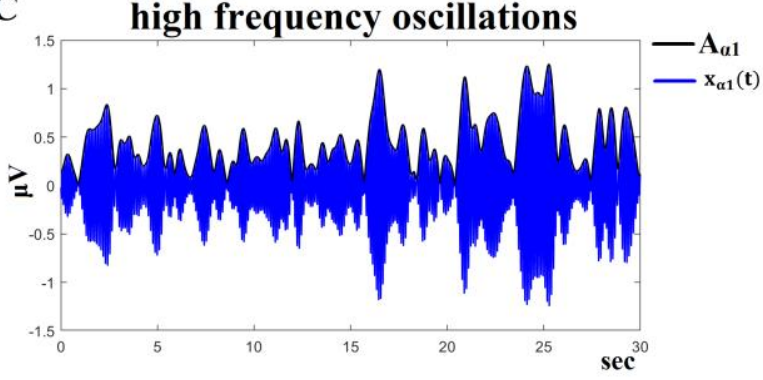

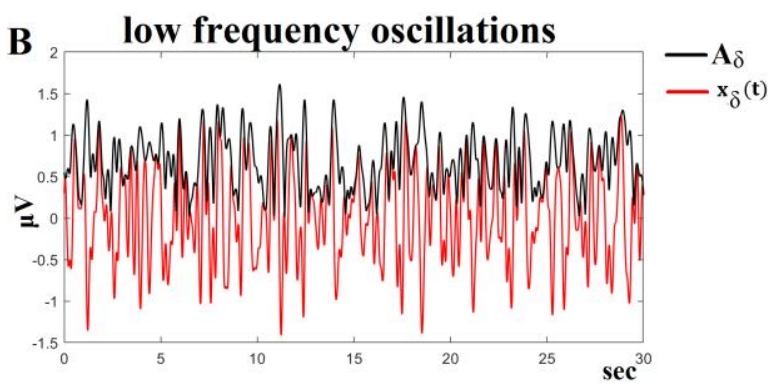

D

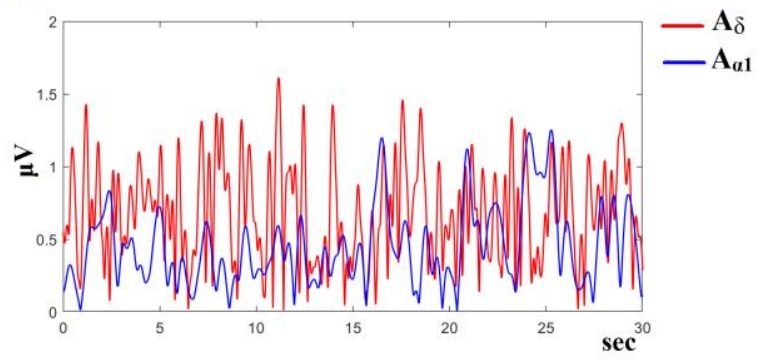

Figure 2. Algorithmic steps for AAC estimation.

Illustrating an epoch of $30 \mathrm{sec}$ length recorded at P4-O2 sensor from the first subject with periodic leg movements during the NREM3 stage (A), we showed the amplitude-to-amplitude coupling between $\delta$ and $\alpha_{1}$ rhythms. To estimate $\delta-\alpha_{1}$ AAC, the raw signal was bandpass filtered into both (B) a low-frequency $\delta(0.5-4 \mathrm{~Hz})$ and $(\mathrm{C})$ a high-frequency $\alpha_{1}(13-20 \mathrm{~Hz})$ components. The envelopes of those quantities were also extracted via Hilbert transform. Their Hilbert envelopes were demonstrated in conjunction with their bandpass filtered time course $(\mathrm{B}, \mathrm{C})$. (D) We then presented into a common plot the envelopes of the bandpass $\delta(4-8 \mathrm{~Hz})$ and $\alpha_{1}(13-20 \mathrm{~Hz})$. The AAC was estimated on these time series using equation 5. 


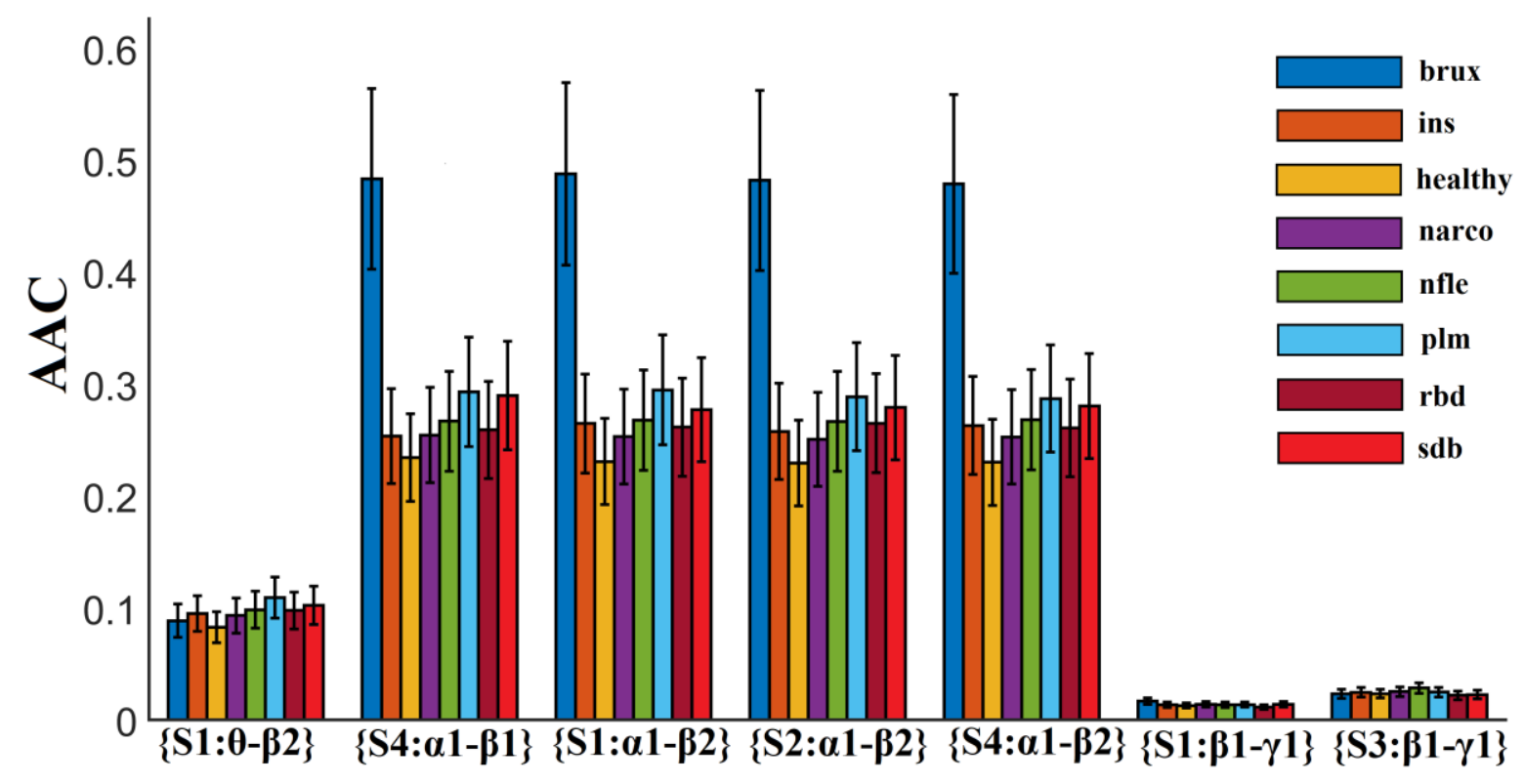

Figure 3. Group-averaged selected AAC values from our random forest model.

\section{(S refers to sleep stage)}

(Abbreviations of subjects' pathology for Figures 3 - 8: Brux - Bruxism, Ins - Insomnia, Healthy - no pathology (controls), Narco - Narcolepsy, Nfle - Nocturnal frontal lobe epilepsy, Plm - Periodic leg movements, Rbd - REM behavior disorder, Sdb - Sleep-disordered breathing) 


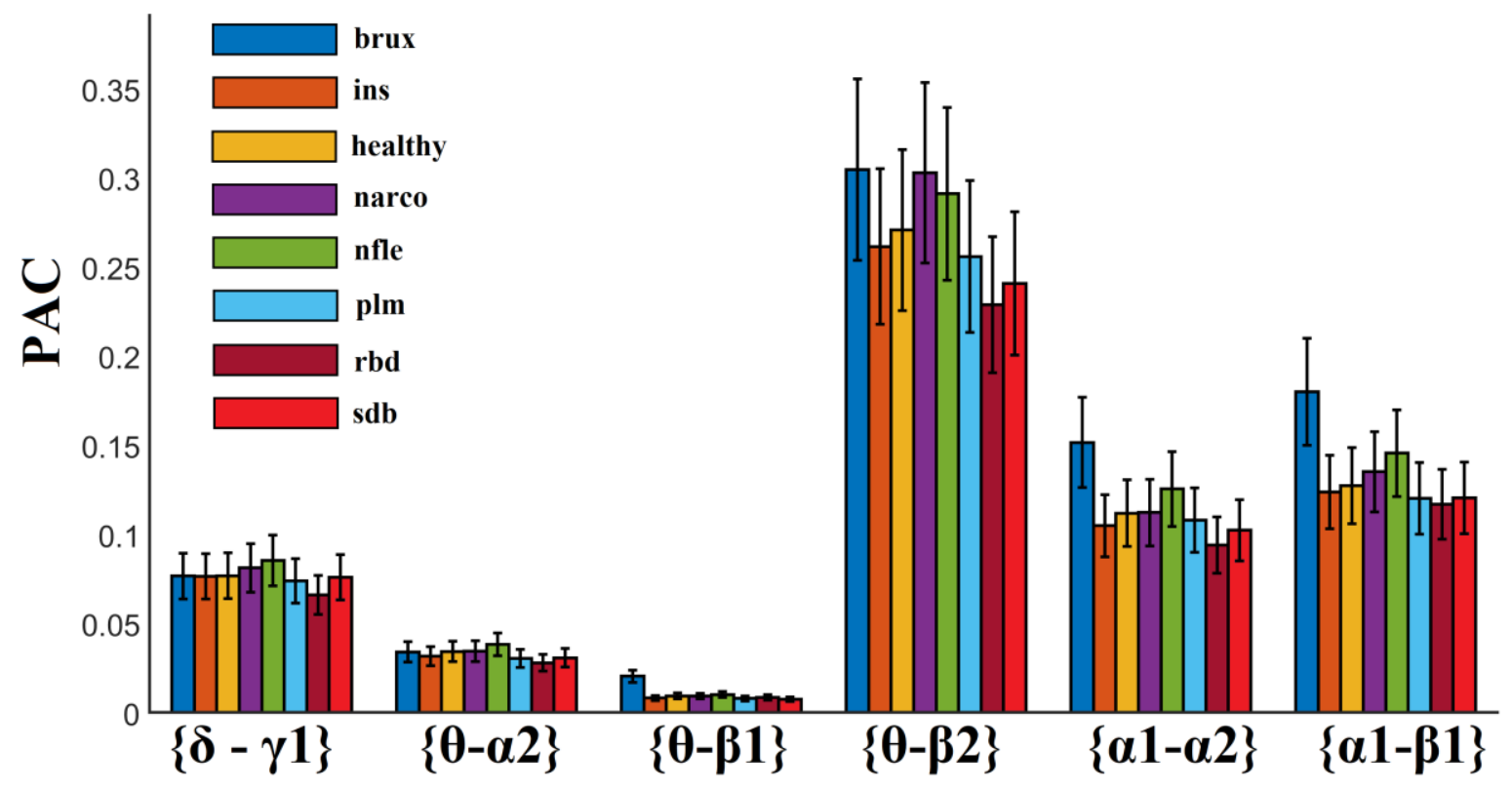

Figure 4 (Sleep stage 1). Group-averaged selected PAC values from our random forest model. (S refers to sleep stage) 
medRxiv preprint doi: https://doi.org/10.1101/2020.06.10.20126268; this version posted January 15, 2021. The copyright holder for this preprint (which was not certified by peer review) is the author/funder, who has granted medRxiv a license to display the preprint in All rights reserved. No reuse allowed without permission.

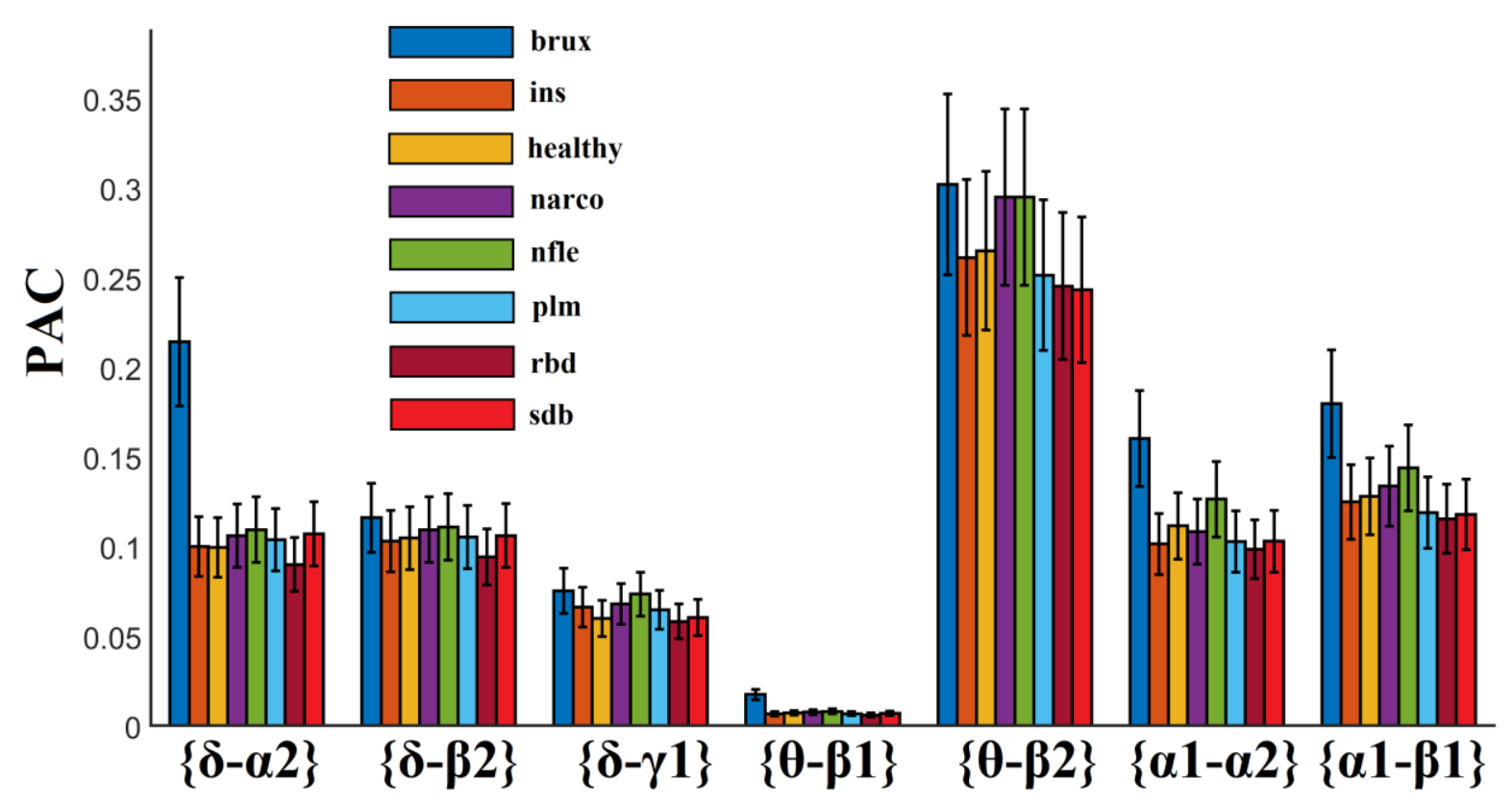

Figure 5 (Sleep stage 2). Group-averaged selected PAC values from our random forest model 


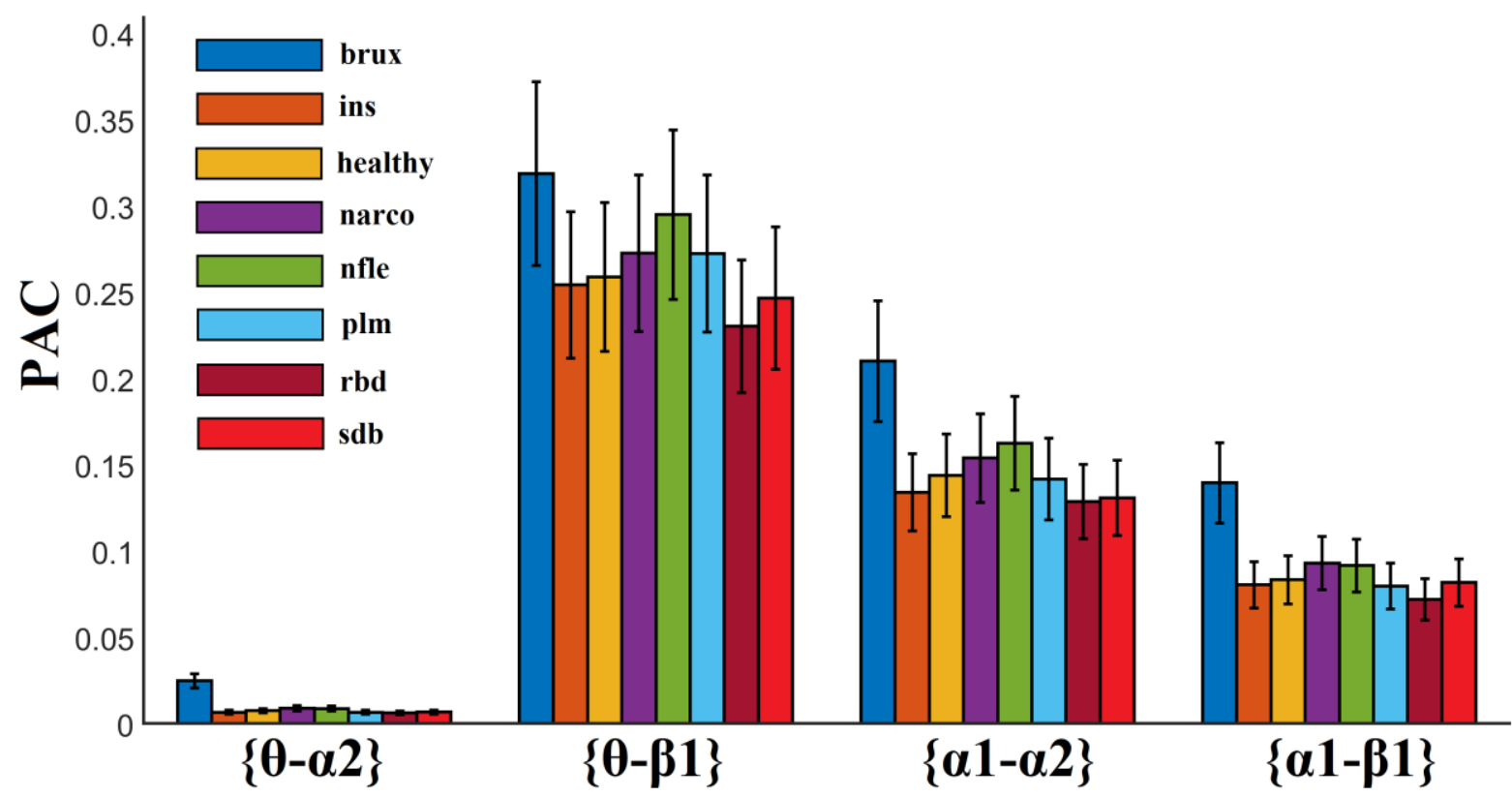

Figure 6 (Sleep stage 3). Group-averaged selected PAC values from our random forest model 
medRxiv preprint doi: https://doi.org/10.1101/2020.06.10.20126268; this version posted January 15, 2021. The copyright holder for this preprint (which was not certified by peer review) is the author/funder, who has granted medRxiv a license to display the preprint in perpetuity.

All rights reserved. No reuse allowed without permission.

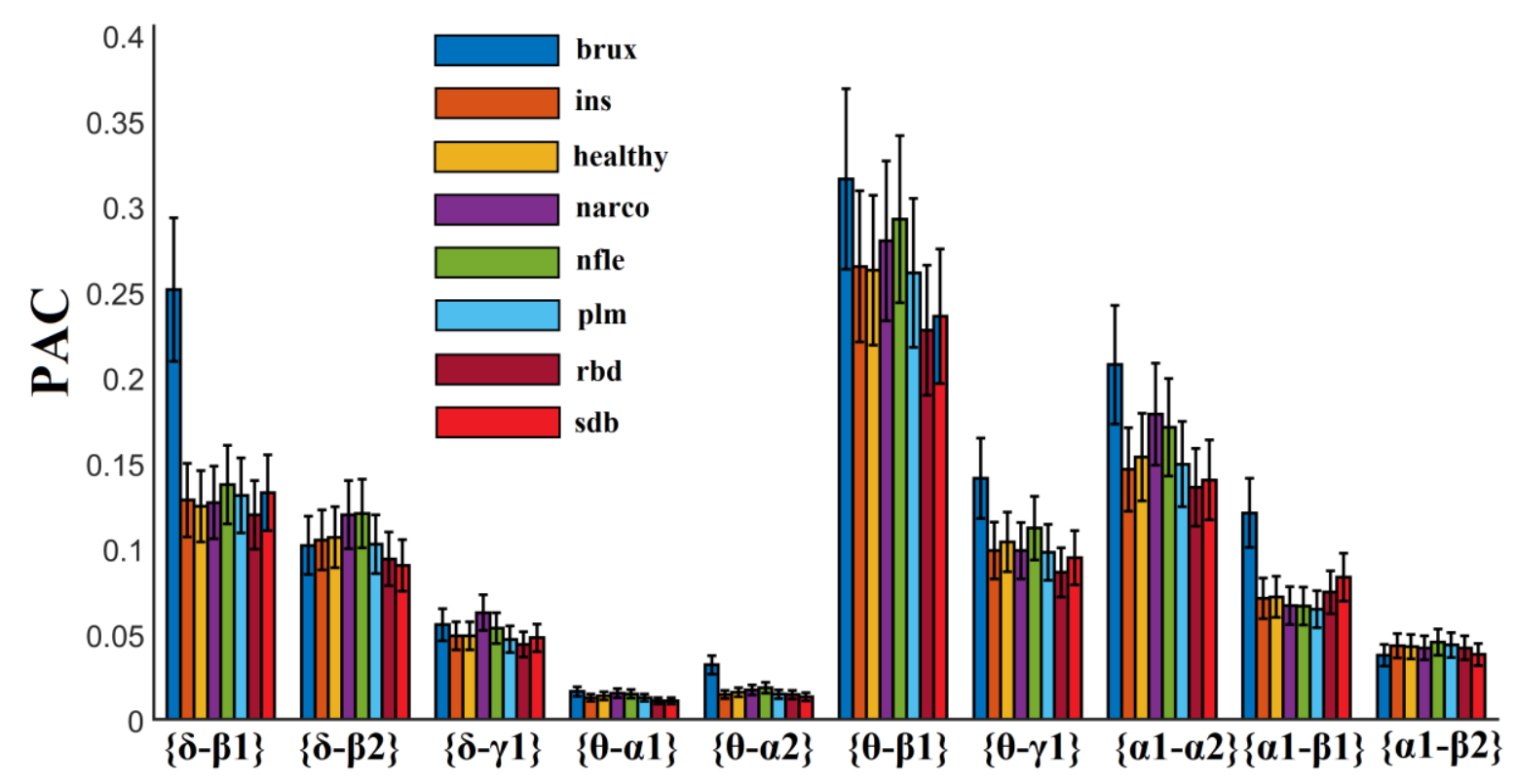

Figure 7 (Sleep stage 4). Group-averaged selected PAC values from our random forest model 
medRxiv preprint doi: https://doi.org/10.1101/2020.06.10.20126268; this version posted January 15, 2021. The copyright holder for this preprint (which was not certified by peer review) is the author/funder, who has granted medRxiv a license to display the preprint in

perpetuity.
All rights reserved. No reuse allowed without permission.

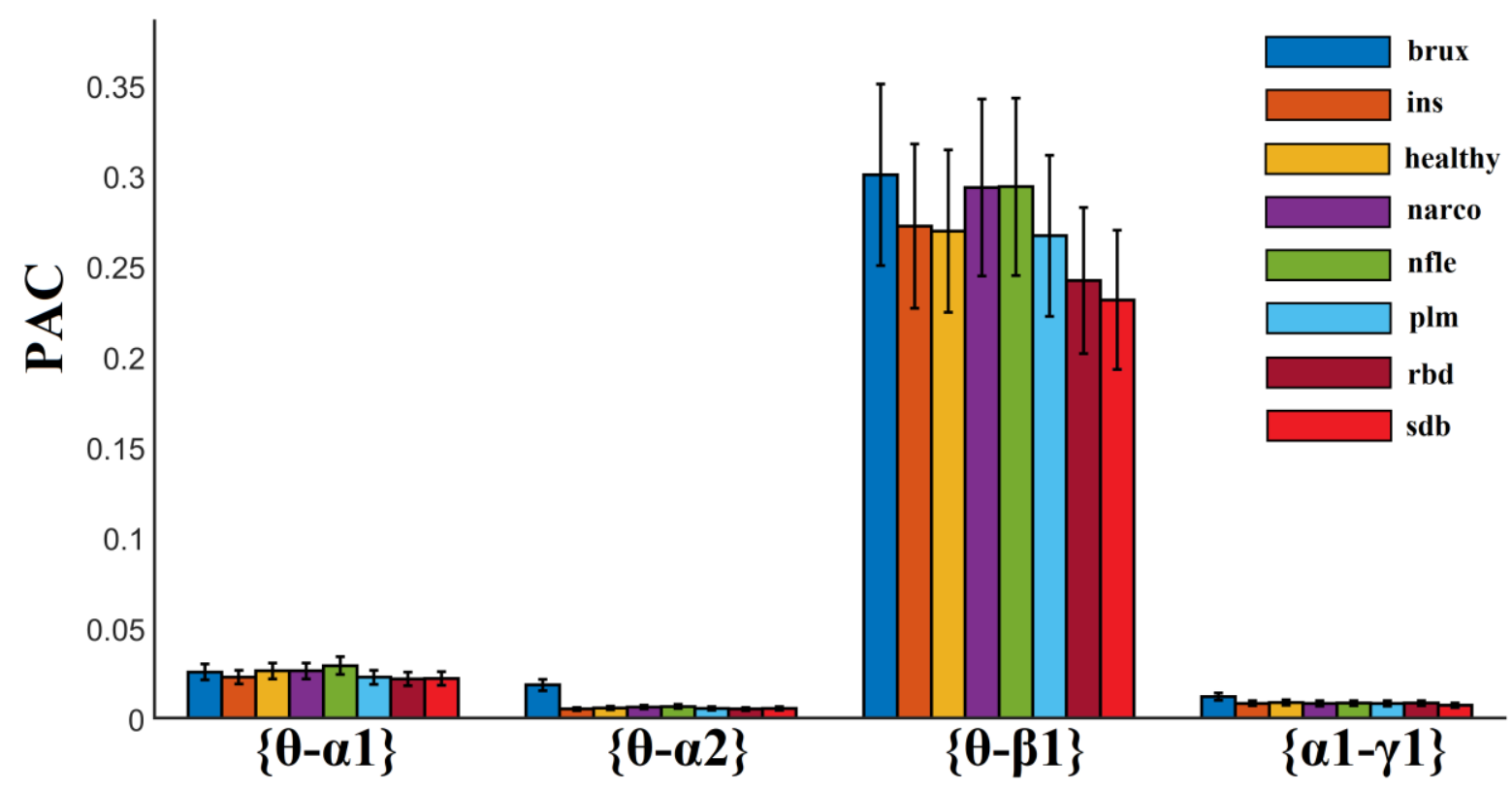

Figure 8 (REM). Group-averaged selected PAC values from our random forest model 
medRxiv preprint doi: https://doi.org/10.1101/2020.06.10.20126268; this version posted January 15, 2021. The copyright holder for this preprint (which was not certified by peer review) is the author/funder, who has granted medRxiv a license to display the preprint in

All rights reserved. No reuse allowed without permission.

Table 1. A summarization of the indexes of the selected subjects per group.

\begin{tabular}{|l|l|l|l|l|l|l|l|}
\hline Bruxism & Insomnia & $\begin{array}{l}\text { Healthy } \\
\text { Controls }\end{array}$ & Narcolepsy & $\begin{array}{l}\text { Nocturnal } \\
\text { frontal } \\
\text { lobe } \\
\text { epilepsy }\end{array}$ & $\begin{array}{l}\text { Periodic leg } \\
\text { movements }\end{array}$ & $\begin{array}{l}\text { REM } \\
\text { behavior } \\
\text { disorder }\end{array}$ & $\begin{array}{l}\text { Sleep- } \\
\text { disordered } \\
\text { breathing }\end{array}$ \\
\hline $\begin{array}{l}\text { brux1, } \\
\text { brux2 }\end{array}$ & isn1-ins9 & $\begin{array}{l}\text { n1-n5, } \\
\text { n10, n11, } \\
\text { n16 }\end{array}$ & $\begin{array}{l}\text { narco1- } \\
\text { narco5 }\end{array}$ & $\begin{array}{l}\text { nfle1- } \\
\text { nfle40 }\end{array}$ & plm1-plm10 & $\begin{array}{l}\text { rbd1- } \\
\text { rbd22 }\end{array}$ & sdb1-sdb4 \\
\hline
\end{tabular}

Table 2. Precision, Recall, F-score and Accuracy performance of the RF model for the P4-O2 EEG sensor

\begin{tabular}{|c|c|c|c|}
\hline Class & Precision & Recall & $\begin{array}{c}\text { F- } \\
\text { score }\end{array}$ \\
\hline brux & $100 \%$ & $50 \%$ & $66.7 \%$ \\
\hline ins & $45.5 \%$ & $55.6 \%$ & $50 \%$ \\
\hline $\mathbf{n}$ & $87.5 \%$ & $87.5 \%$ & $87.5 \%$ \\
\hline narco & $100 \%$ & $20 \%$ & $33.3 \%$ \\
\hline nfle & $71.2 \%$ & $92.5 \%$ & $80.5 \%$ \\
\hline plm & $80 \%$ & $40 \%$ & $53.3 \%$ \\
\hline rbd & $85 \%$ & $77.3 \%$ & $81 \%$ \\
\hline sdb & $100 \%$ & $50 \%$ & $66.7 \%$ \\
\hline $\begin{array}{c}\text { Macro- } \\
\text { average }\end{array}$ & $\mathbf{8 3 . 7 \%}$ & $\mathbf{5 9 . 1 \%}$ & $\mathbf{6 4 . 9 \%}$ \\
\hline Accuracy & \multicolumn{3}{|c|}{$\mathbf{7 4 \%}$} \\
\hline
\end{tabular}


medRxiv preprint doi: https://doi.org/10.1101/2020.06.10.20126268; this version posted January 15, 2021. The copyright holder for this preprint (which was not certified by peer review) is the author/funder, who has granted medRxiv a license to display the preprint in

All rights reserved. No reuse allowed without permission.

Table 3. Confusion matrix of the RF model based on the selected features extracted from P4-

$\mathrm{O} 2$

\begin{tabular}{|c|c|c|c|c|c|c|c|c|}
\hline Class & $\begin{array}{c}\text { brux } \\
\text { predicted }\end{array}$ & $\begin{array}{c}\text { ins } \\
\text { predicted }\end{array}$ & $\begin{array}{c}\mathbf{n} \\
\text { predicted }\end{array}$ & $\begin{array}{c}\text { narco } \\
\text { predicted }\end{array}$ & $\begin{array}{c}\text { nfle } \\
\text { predicted }\end{array}$ & $\begin{array}{c}\text { plm } \\
\text { predicted }\end{array}$ & $\begin{array}{c}\text { rbd } \\
\text { predicted }\end{array}$ & $\begin{array}{c}\text { sdb } \\
\text { predicted }\end{array}$ \\
\hline $\begin{array}{c}\text { brux } \\
\text { real }\end{array}$ & 1 & 0 & 0 & 0 & 1 & 0 & 0 & 0 \\
\hline $\begin{array}{c}\text { ins } \\
\text { real }\end{array}$ & 0 & 5 & 0 & 0 & 3 & 0 & 1 & 0 \\
\hline $\begin{array}{c}\text { n } \\
\text { real }\end{array}$ & 0 & 0 & 7 & 0 & 0 & 0 & 1 & 0 \\
\hline $\begin{array}{c}\text { narco } \\
\text { real }\end{array}$ & 0 & 0 & 0 & 1 & 4 & 0 & 0 & 0 \\
\hline $\begin{array}{c}\text { nfle } \\
\text { real }\end{array}$ & 0 & 3 & 0 & 0 & 37 & 0 & 0 & 0 \\
\hline $\begin{array}{c}\text { plm } \\
\text { real }\end{array}$ & 0 & 3 & 0 & 0 & 3 & 4 & 0 & 0 \\
\hline $\begin{array}{c}\text { rbd } \\
\text { real }\end{array}$ & 0 & 0 & 1 & 0 & 4 & 0 & 17 & 0 \\
\hline $\begin{array}{c}\text { sdb } \\
\text { real }\end{array}$ & 0 & 0 & 0 & 0 & 0 & 1 & 1 & 2 \\
\hline
\end{tabular}

